\title{
DESCONTAMINAÇÃO $Q$ UTMCO-MICROBIOLOGICA EM AMBIENTES hospitalares POR MEIO DE PURIFICADor Iônico
}

\author{
Celina de Arruda Camargo* \\ Cecília Mattos Ubson * * \\ Adnei Melges de Andrade ** \\ Rudolph Uri Hutsler ${ }^{\star \star \star \star}$ \\ Rubens Franci de Vasconcelos ${ }^{\star \star \star \star \star ~}$ \\ Daisy Baptista Stape $e^{\star \star \star \star \star}$
}

\section{N T R O D U Ç Ã O}

A ocorrência de partículas de origem orgânica, inorgânica e de micro organismos vivos em suspensão no ar, quando em níveis altos, é o que se chama de poluição ou contaminação. Salvo em casos ultraparticulares, o ar que se respira e que está presente em nosso meio é poluído, contaminado tanto química como bacteriologicamente.

O efeito dessa contaminação sobre o homem é muito amplo e em todos os casos nocivo. Algumas manifestações mais diretas e evidentes do efeito da poluição química são as caracterizadas por doenças da pele e afecções do aparelho respiratório.

Do ponto-de-vista da contaminação bacteriológica, os riscos são ainda maiores, principalmente quando se trata de ambiente hos-

${ }^{*}$ Enfermeira - Supervisora de Educação em Serviço - D.H.O.T. Hospital das Clínicas - SP

$\left.{ }^{\star \star}\right)$ Professor Assistente, Doutor do Inst. Ciências Biomédicas da U.S.P. Bacteriologista do G.T.C.I. do H. Clínicas da U.S.P.

$\left({ }^{\star \star \star}\right)$ Professor Assistente do Departamento de Engenharia de Eletricidade da E.P.U.S.P.

$\left({ }^{\star \star \star \star}\right)$ Assistente Doutor da Clínica de Doenças Tropicais e Infecciosas do $H$. Clínicas da F.M.U.S.P. e Coordenador do G.T.C.I. do H.C. da FMUSP

$\left({ }^{\star \star \star \star}\right)$ Médico Assistente - Epidemiologista do G.T.C.I. do H.C. da FMUSP

$(\star \star \star \star \star \star ;)$ Enfermeira do G.T.C.I. da FMUSP 
pitalar onde a flora bacteriana existente é constituída, em sua maioria, por mutantes resistentes aos antibióticos mais utilizados e pelo fato de encontrar alí o organismo humano com resistência diminuída. Os pacientes hospitalizados e submetidos à intervenção cirúrgica ainda que pequena, como por exemplo, uma traqueotomia, abre novas portas de entrada para a invasão direta dos micro organismos existentes no ar ambiente.

A tecnologia moderna tem proposto inúmeras tentativas visando minimizar os efeitos da contaminação, quer limitando-a nas fontes, quer pela anulação de seus efeitos. Muitos métodos têm sido utilizados para descontaminação de ambientes. Esses métodos são baseados em sua maioria, no emprego de metanal que, embora comprovadamente eficiente, tem a desvantagem de tornar inabitável o ambiente pelo espaço de algumas horas. Com o objetivo de eliminar eficazmente a poluição ambiente, principalmente no âmbito hospitalar em que, devido à instalação de floras mutantes, antibiótico resistonte, certas populações bacterianas prevalecem endemicamente, foi desenvolvido um aparelho baseado em princípio de filtragem eletrostática $(2,4,9,10)$, destinado a filtrar e descontaminar química $\mathrm{e}$ bacteriologicamente $o$ ar.

O propósito desta investigação foi, pois, comprovar a eficácia do aparelho purificador em ambiente hospitalar, aplicado sem remoção dos pacientes.

\section{MATERIAL E METODOS}

O purificador eletrostático utilizado $\left(^{*}\right)$ combina dois processos de filtragem. Um mecânico, representado por associação de filtros de espuina e carvão ativo, e outro eletrostático, que utiliza fortes campos elétricos para captar as partículas em suspensão no ar. O aparelho canaliza por aspiração a passagem do ar, através dos filtros com a ajuda de um potente ventilador radial (fig. 1).

$\mathrm{Na}$ primeira etapa de filtragem, através da espuma sintética e do carvão ativo, são removidas as macropartículas e os vapores orgânicos respectivamente, processando-se a desodorização e purificação parcial do ar.

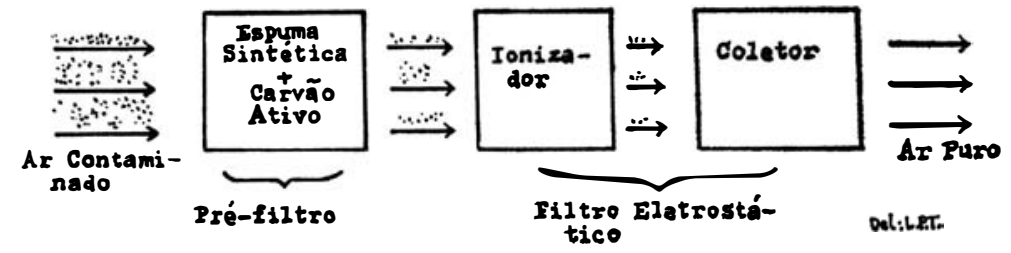

(*) Jomercializado com o nome de Purificadoi iônico de Ar "ETAPA" mod. P2 
Na segunda etapa da filtragem, as partículas remanescentes arlquirem carga elétrica definida, imposta pelo ionizador; continuando no fluxo de ar, são atraídas e captadas pelo coletor. A ionização das partículas é obtida através de gradiente de campo elétrico promovido por uma série de placas metálicas e finos fios de aço paralelos e equi-espaçados. Os fios são mantidos a um potencial da ordem (le 6 Quilowatt (CC) e as placas em terra. Ao passarem pelo coletor, as partículas, eletricamente carregadas, são retidas pelo campo elétrico.

À saída do filtro obtem-se ar puro.

\section{CONTROLE BACTERIOLÓGICO DA DEGERMAÇÃO}

Dois métodos foram utilizados:

a) um dinâmico, em que as medidas foram feitas utilizando-se 152 placas, com meio de ágar — sangue, com $66 \mathrm{~cm}^{2}$ de superfície. Algumas placas foram expostas ao ambiente inicialmente contaminado, sequencialmente, por períodos de 15 minutos. Estas eram afixadas ao purificador por meio de um anel metálico entre o orifício de entrada e o primeiro pré-filtro no fluxo do ar aspirado. Esse procedimento inicial permite obter os valores médios dos níveis de contaminação ambiente antes da filtragem. Para se estudar a (linâmica da purificação, as placas foram expostas por períodos de 15 minutos à saída do ar purificado.

b) outro, estático, em que 10 placas deixadas sobre o piso, no. centro da sala por períodos de 180 minutos, antes do tratamento e após a descontaminação. O objetivo destes experimentos foi o de verificar no primeiro caso a dinâmica da filtragem e no segundo a eficiência real da assepsia do ar ambiente. Os tempos de exposição das placas foram estabelecidos com base nas características do purificador.

\section{AMBIENTES TRATADOS}

Trabalhou-se em salas do ambulatório de controle de tratamento da DHOT, com volumes de 32 e $90 \mathrm{~m}^{3}$. A medida dos níveis de contaminação foi iniciada duas horas após o início do atendimento de pacientes. Nas salas menores fazem-se rotineiramente curativos infectados ou não, e, na sala maior, são removidos os aparelhos de gesso dos pacientes. Esta última é uma sala com alto nível de contaminação pela natureza do trabalho aí realizado.

\section{I - METODO DINÂMICO}

Os níveis de contaminação das salas mostraram ser função dos grupos de pacientes nela atendidos, grupos que diferem por idade, sexo e número. 
A análise das medidas mostra que os níveis de contaminação são, na ordem crescente, maiores para grupos de meninas, meninos, mulheres e homens (Tabela 1).

T A B E L A I

CONTROLE BACTERIOLÓGICO DA DEGERMAÇÃO MÉTODO DINÂMICO

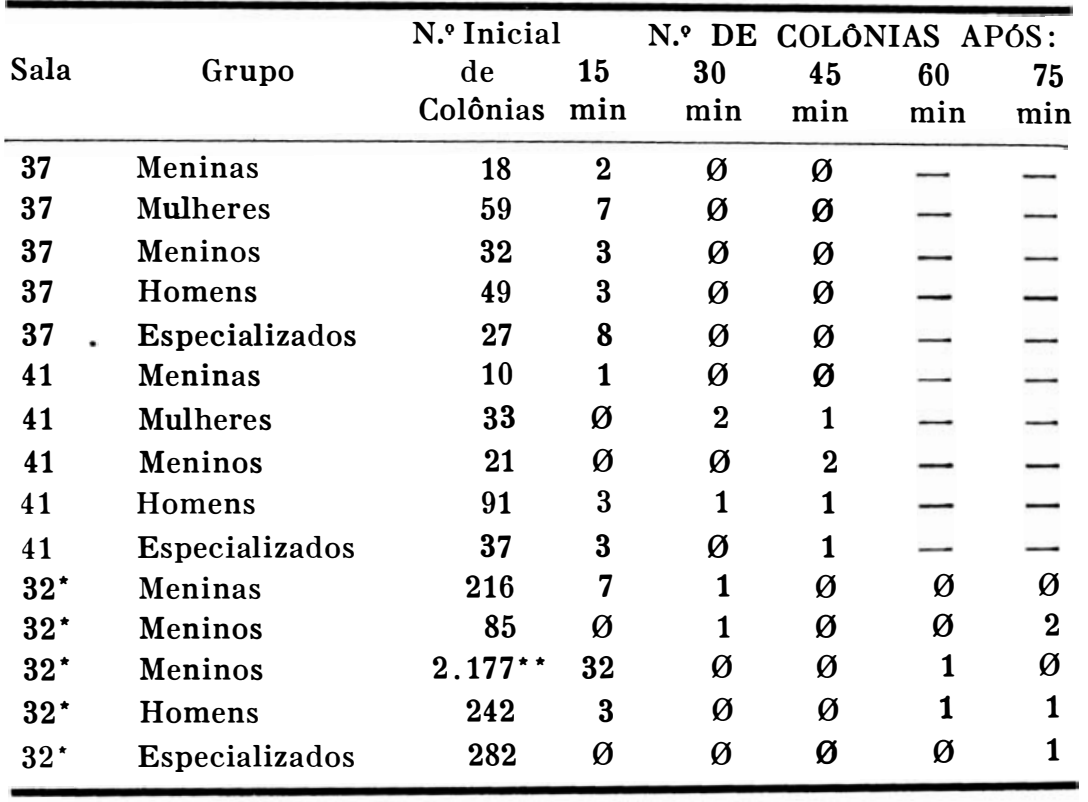

( * ) Sala com $90 \mathrm{~m}^{3}$ em que as exposições foram de 75 minutos. Nas demais salas as exposições foram de 45 minutos.

$\left({ }^{\star *}\right)$ Medida feita após retirada de gesso pelvipodálico com ferimento infectado num dos membros.

\section{II - Método eSTÁtico}

Conforme já se descreveu, este método consistiu na comparação de medidas feitas antes e depois da purificação do ar ambiente, por meio de placas colocadas sobre o piso das salas trabalhadas.

A exposição de placa na sala de $90 \mathrm{~m}^{3}$, mantida com vitrais abertos, revelou uma contagem de 1.200 colônias. $O$ ar foi filtrado por período de 60 minutos; uma segunda placa foi exposta por igual período, revelando apenas 61 colônias. Esse resultado indica eficiência superior a $95 \%$ na filtragem do ar ambiente. 


\section{DISCUSSÃO}

$\mathrm{Na}$ prevenção de infecção intra-hospitalar, a descontaminação do ar ambiente pode ter importância, considerada especialmente a infecção de origem exógena.

As possibilidades de descontaminação podem ser:

$$
\text { 1.7 - Físicas }
$$

a) por ventilação artificial, extremamente cara, ruidosa e difícil de ser adaptada em ambientes para os quais não havia sido prevista (7);

b) por irradiação ultravioleta em comprimento de onda de 0,2.536 um, perigosa para os circunstantes, doentes e pessoal hospitalar, especialmente com relação aos olhos (12);

c) filtragem através de materiais diversos, que pode chegar a uma eficiência de $97 \%$, retendo partículas de até 0,3 um (3).

\section{Q Químicas}

Por formalização ou dispersão de outros agentes químicos, geralmente incompatíveis com a presença humana no local, prestando-se a desinfecção termna le oferecendo resultados variáveis por vezes duvidosos.

A população bacteriana do ar em ambiente hospitalar atinge números altos. Em berçários os Gram positivos patogênicos foram avaliados em $0,7 \%$ da população anemófila e os Gram negativos patogênicos em $0,15 \%$ (15). E provável que com o aumento da prevalência das infecções hospitalares causadas por Gram negativos nestes últimos anos, a proporção de partículas aéreas contendo Gram negativos seja maior.

Os estafilococos foram melhor estudados, como contaminantes aéreos. As partículas aéreas que os contém, têm de 8 a 18 um de diâmetro e contêm em geral 4 cocos. A quantidade dessas partículas pode ser medida através de avaliação aproximadas, mas simples, quando se admite que a contagem de partículas, depositadas por pé quadrado de superfície de placa de cultura por minuto, é igual ao número de partículas contidas em um pé cúbico de ar (13).

Em uma sala de operação em atividade calma, a contagem de partículas contendo bactérias não deve exceder a 5 por pé cúbico de ar. De preferência esse número não deve exceder a 2 por pé cúbico e na sala vazia a contagem deve ser inferior a uma partícula 
por pé cúbico (14). Nas enfermarias, o ar deve conter menos de 10 partículas hospedeiras de bactérias por cada 100 pés cúbicos de ar. Essa contagem é muito aumentada pela movimentação de lençóis e outros materiais que funcionam como reservatórios; (8) a movimentação intempestiva de curativos contaminados pode elevar a contagem a 100 e às vezes a mais de 500 partículas hospedeiras de estafilococos por 100 pés cúbicos (11).

O ar confinado, como o é o das dependências hospitalares, é muito menos bactericida que o ar corrente de espaços abertos. Provavelmente as paredes e outras estruturas absorvem complexos gasosos de ozona e hidrocarbonetos insaturados, que agem como bactericidas (1). O ar condicionado comum de janela faz recircular as partículas bacterianas (3).

A redução na contagem de colônias, observada com o uso do aparelho utilizado para as nossas observações foi bastante acentuada, resultando no crescimento de poucas colônias após o uso do aparelho por período de 15 a 75 minutos. A possibilidade de realizar descontaminação bacteriana aérea em desinfecções concorrentes e terminais, parece ser muito fácil na prática e muito promissora em eficiência, com uso deste aparelho.

Vale lembrar, que com essa metodologia não se faz pressão antimicrobiana, o que ocorre nas desinfecções realizadas com agentes químicos e é indesejável, pois resulta, em prazo maior, no aumento da presença de germes Gram negativos, representados por sua raça mais resistente.

Este fato tem sido observado também em decorrência do uso intensivo da antimicrobianoterapia (5).

\section{RESUMO}

Apresenta-se um aparelho purificador de ar baseado em princípios de filtragem eletrostática. Efetuam-se observações em ambiente hospitalar de atendimento ambulatorial da Clínica Ortopédica e Traumatológica com volumes de $32 \mathrm{~m}^{3}$ e $90 \mathrm{~m}^{3}$.

Foram realizadas contagens de colônias em placas de cultura recebendo ar tratado pelo aparelho, durante intervalos de tempo que variavam de 15 a 75 minutos.

A redução do número de colônias nas placas que receberam o ar tratado foi muito grande, quando comparada aos das que receberam ar não tratado. 
A eficiência do aparelho na metodologia comparativa de contagem de colônias antes e após a purificação do ar fói próxima a $100 \%$.

Discutem-se algumas das implicações de contaminação bacteriana do ar ambiente hospitalar e as perspectivas que o método de purificação of erece.

\section{BIBLIOGRAFIA}

1 - BENBOUGH, J.E.; \& HOOD, A.M. - Viricidal activity of pen Sir. J. Hyg. Camb. 69: 619-626, 1971.

2 - CAGE, J.M. - Theory and Aplication of Industrial Eletronics, McGraw Hill, New York, 1951.

3 - CORRIEL, L.L. - Use of Laminar Flow in Surgery in Proceedings of the International Conference on Nosocominal Infections, Center for Disease Control, pg. 225-229. Chicago Waverly Press Inc., Baltimore, 1971.

4 - DWYER, J.L. Contamination Analysis and Control. Reinhold Publishing Corporation, New York, 1966.

5 - ISENBERG, H.D. \& BERKMAN, J.L. - The role of drug resistant and drug selected bacteria in nosocominal disease. Ann. N.Y. acd. Sci. 176. 53-58, 1971.

6 - LAUfman, H. - What's Wrong with Our Operating Rooms. Am. J. Surg. 122: 322-343, 1971.

7 - LIDWELL, O.M. - Hospital uses of unidirectional ("laminar") airflow. Proceedings of the International Conference on Nosocominal Infections. Center for Disease Control, pg. 207-215. Chicago. Waverly Press Inc. Baltimore, 1971.

8 - LITSKI, B.Y. - Germamake trouble when nurses make beds. Modern Hosp. 108: 61-63, 1971.

9 - PENNey, G.W. - A New Electrostatic Precipitador, Elec. Eng. 56, 159, 1937.

10 - SCHMIDT, W.A. and ANDERSON, E. - Electrical Precipitation Elec. Eng., 57, 533, 1938. 
11 - WilliamS, R.E.O.; BLOWERS, R.; GARROD, L.P. \& SHOOTER, R.A. - Hospital Infection; $2 .^{\circ}$ ed. pag. 372, London. Leoyd-Luke (medical books) Ltd. 1966.

12 - Ibid, pag. 327.

13 - Ibid, pag. 36 .

14 - Ibid. pag. 373.

15 - WINTON, F.W. \& KEAY, A.J. - Bacteria in a Hospital nursery laboratory and clinical studies, Stlyg (Lond) 66: 325-342, 1968. 